\title{
Detection of COVID-19 Cases with Fuzzy Classifiers Using Chest Computed Tomography
}

\author{
Aleyna Kökten*, Volkan Kılıç \\ İzmir Katip Çelebi University, Faculty of Engineering and Architecture, Departmant of Electrical and Electronics Engineering, İzmir, Turkey, (ORCID: 0000-0002- \\ 2091-0453,0000-0002-3164-1981), aleynakoktenn@gmail.com, volkan.kilic@ikc.edu.tr
}

(3rd International Congress on Human-Computer Interaction, Optimization and Robotic Applications June 11-13, 2021)

(DOI: 10.31590/ejosat.950941)

ATIF/REFERENCE: Kökten, A. \& Kılıç, V. (2021). Detection of COVID-19 Cases with Fuzzy Classifiers Using Chest Computed Tomography. European Journal of Science and Technology, (26), 68-72.

\begin{abstract}
The novel coronavirus 2019 (COVID-19) is still spreading rapidly since it first appeared in Wuhan city of China in December 2019, resulting in a worldwide pandemic. Early detection of positive cases plays a key role in preventing the further spread of the epidemic which leads to the development of diagnostic methods that give rapid and accurate responses for the detection of COVID-19. Previous studies confirmed that chest computed tomography (CT) is an indispensable tool for early screening and diagnosing of COVID-19 cases. As a result of examinations on CT scans, a radiological finding that is called ground-glass opacity, causing color, and texture change, was found in the lung of a person with COVID-19. Due to the carelessness of radiologists who work long hours and the misdiagnosis resulting in confusion of the findings with different diseases, an automatic system that helps radiologists is needed. In this paper, we present a new approach based on fuzzy classification for the detection of COVID-19 using 3D CT volumes. In the proposed approach, the skewness, kurtosis, and average statistical features of 3D CT images of patients consisting of two classes, COVID and Normal, are calculated and the value ranges are determined for both classes. Three statistical features and value ranges are used as membership functions in the development of fuzzy logic classifier. The proposed approach provides rapid and accurate diagnostics in terms of COVID vs. Normal (binary classification) under a user-friendly interface. Experimental evaluations demonstrate that our approach has great potential for radiologists to validate their initial screening and improve early diagnosis, isolation, and treatment, which contributes to infection prevention and control of the epidemic.
\end{abstract}

Keywords: COVID-19, fuzzy classification, CT images, ground-glass opacity, statistical features.

\section{Bilgisayarlı Göğüs Tomografisi Kullanılarak Bulanık Sınıflandırıcılarla COVID-19 Vakalarının Tespiti}

\section{$\ddot{O} \mathbf{z}$}

Yeni koronavirüs salgını (COVID-19), ilk olarak Aralık 2019'da Çin'in Wuhan şehrinde ortaya çıktığından beri hızla yayılmakta ve dünya çapında pandemiye neden olmaktadır. Pozitif vakaların erken teşhisi, COVID-19 tespiti için hızlı ve doğru yanıtlar veren tanı yöntemlerinin gelişmesine yol açan salgının daha da yayılmasını önlemede önemli bir rol oynar. Önceki çalışmalar, göğüs bilgisayarlı tomografisinin (BT) COVID-19 vakalarının erken taranması ve teşhisi için gerekli bir araç olduğunu doğrulamıştır. İncelemeler sonucu COVID-19 hastalığına yakalanmış bir insanın akciğer BT taramalarında buzlu cam opasitesi adı verilen, renk ve doku değişikliğine sebep olan bir radyolojik bulgu bulunmuştur. Uzun saatler çalışan radyologların dikkatsizliği ve bulguların farklı hastalıklarla karıştırılmasıyla sonuçlanan yanlış tanı nedeniyle radyologlara yardımcı olan otomatik bir sisteme ihtiyaç doğmaktadır. Bu çalışmada, 3D BT kesitleri kullanılarak COVID-19 tespiti için bulanık sınıflandırmaya dayalı yeni bir yaklaşım sunuyoruz. Önerilen yaklaşımda COVID ve Normal olmak üzere iki sınıftan oluşan hastaların 3D BT görüntülerinin çarpıklık, basıklık ve ortalama istatistiksel özellikleri hesaplanır ve her iki sınıf için değer aralıkları belirlenir. Hesaplanan üç istatistiksel özellik ve değer aralıkları geliştirilen bulanık mantık sınıflandırıcısında üyelik fonksiyonu olarak kullanılır. Uygun üyelik fonksiyonları ve kural tabanıyla ile geliştirilen bulanık sınıflandırıcı 3D BT taramalarını sınıflandırarak çıkışa verir. Bu bulanık sınıflandırıcı sistem geliştirilen arayüz ile birleştirerek radyologlara yardımcı bir sistem tasarlanmıştır. Önerilen yaklaşım, kullanıcı dostu bu arayüz altında COVID ve Normal (ikili sınıflandırma) açısından hızlı ve

\footnotetext{
${ }^{*}$ Corresponding Author: İzmir Kâtip Çelebi University, Faculty of Engineering and Architecture, Departmant of Electrical and Electronics Engineering, İzmir, Türkiye (ORCID: 0000-0002-2091-0453), aleynakoktenn@gmail.com
} 
doğru teşhis sağlamaktadır. Deneysel değerlendirmeler, yaklaşımımızın radyologların ilk taramalarını doğrulaması ve erken tanı, izolasyon ve tedaviyi iyileştirmesi için büyük bir potansiyele sahip olduğunu ve bu da enfeksiyonun önlenmesine ve salgının kontrolüne katkıda bulunduğunu göstermektedir.

Anahtar Kelimeler: COVID-19, bulanık mantık sınıflandırıcı, BT görüntüleri, buzlu cam opasitesi, istatistiksel özellikler.

\section{Introduction}

COVID-19 is a pandemic disease that infects the lungs of people, resulting in serious damage to their sense of smell, taste, and even the loss of people's lives. To prevent this epidemic, various test methods have been developed including real-time reverse transcriptase-polymerase chain reaction (rRT-PCR). The PCR tests can be performed with a nasopharyngeal swab, nasal swab, or sputum sample which takes up to two days to view the results. However, the PCR test performed in the early stages of the disease causes $40 \backslash \%$ false-negative results which are also associated with low accuracy (Carpenter, Mudd, West, Wilber, \& Wilber, 2020). These disadvantages in PCR tests can cause many patients to be diagnosed incorrectly or not receive appropriate treatment in time. Considering the rapid spread of the epidemic, the computed tomography method which is a medical imaging tool is used for the rapid and high accuracy diagnosis of COVID19 disease (Ai et al., 2020). The computed tomography method gives more reliable results compared to the PCR test in the diagnosis of COVID-19 disease with an accuracy of $98 \%$ (ÖKÇÜN et al.).

The patients with COVID-19 infection have abnormal situations (Barstugan, Ozkaya, \& Ozturk, 2020) which can be seen in different regions or slices of their chest CT scans. It takes 21.5 minutes for a specialist doctor like radiologists to examine all of the slices and diagnose the patient (Wu et al., 2021). However, the impact on fatigue of long sequences of day and night shifts may cause radiologists to misdiagnose which jeopardizes many people's lives. Therefore, auxiliary tools to improve diagnosis accuracy are critical and they can also contribute to ease the burden on the health care system.

Theoretical and algorithmic advances in medical imaging and fuzzy logic have led to the emergence of more sophisticated tools for the diagnosis of many diseases (Samuel, Saravanan, \& Devi, 2007), (Kuruvilla \& Gunavathi, 2015), (Kamiya et al., 2014). A fuzzy logic-based lung nodule detection system was proposed in (Samuel et al., 2007) which fed the nodule areas to the fuzzy logic system in order to detect cancer. Statistical and gray level coformation matrix parameters calculated from segmented chest CT images were used in adaptive-network based fuzzy inference systems for the classification of lung cancer (Kuruvilla \& Gunavathi, 2015).

In this study, we propose a fuzzy logic model to classify chest CT scans as COVID-19 or Normal based on ground-glass opacity which is a radiological finding used in COVID-19 cases. Statistical features like skewness, kurtosis, and mean were calculated from chest CT scans to feed the fuzzy logic model. The proposed system was integrated with our COV-FUZZY interface which diagnoses the case as either COVID-19 or Normal. The COV-FUZZY calculates the statistical features to feed into the proposed fuzzy logic model. Then, CT scans are classified based on statistical features and fuzzy rules.

The rest of this paper is organized as follows: Section 2 presents the theoretical background of the fuzzy logic model for COVID-19 diagnosis. Section 3 introduces the general structure of our proposed model and our custom-designed interface. Dataset and results of the proposed model are discussed in Section 4. Closing remarks are explained in Section 5.

\section{Fuzzy Logic}

Fuzzy logic enables ambiguous or imprecise linguistic concepts (e.g, very long, long, medium, short, very short) to be characterized between precise expressions which are easily perceived by the computer (Barro \& Marín, 2001), (Tiryaki \& Kazan, 2007). The classical logic based on these precise expressions that are the standard set of truth values (degrees) consists of $(0,1)$, where 0 represents "totally false" and 1 represents "totally true". As opposed to the classical logic, the values 0 and 1 are seen as boundary values, not absolute values in fuzzy (Kamal \& Ibrahim, 2018). The truth values may take any values in this range.

The fuzzy logic system consists of four components including: fuzzier, fuzzy inference engine, fuzzy rule base, and defuzzification (Helmy, Al-Jamimi, Ahmed, \& Loqman, 2013) as shown in Figure 1. The fuzzier converts the net (crisp) inputs into fuzzy values using membership functions. These membership functions could be triangle, trapezoid, and Gaussian which are commonly used. Each fuzzy set has one of these membership functions and the elements of the fuzzy set have a degree of membership (Mercan \& Kılıç, 2020). Fuzzy logic rule base consists of an 'if-then' decision system. Membership degrees coming from fuzzier go through the fuzzy rule base to generate fuzzy outputs. The fuzzy inference system employs different inference methods including Mamdani and Takagi-Sugeno (Anand \& Tyagi, 2012). In the Takagi-Sugeno method, the output is a linear or constant value (Mercan \& K1lıç, 2020). So, the Takagi-Sugeno method does not need the defuzzification part. The Mamdani method has a defuzzification part at the last part of the fuzzy logic architecture. In the defuzzification part, the fuzzy outputs coming from the fuzzy inference engine are converted to net (crisp) values.

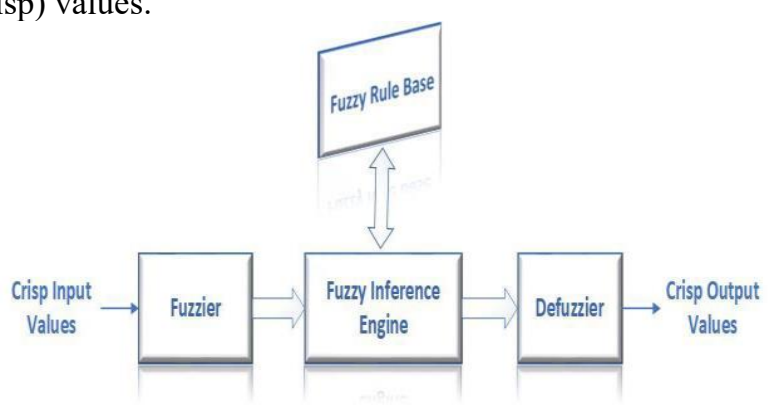

Figure 1. Fuzzy logic architecture 
Table 1. Lower limit, mean and upper limit of statistical features

\begin{tabular}{ccccccccccccc}
\hline & \multicolumn{3}{c}{ MEAN } & \multicolumn{4}{c}{ SKEWNESS } & & & \multicolumn{2}{c}{ KURTOSIS } \\
\hline mf & $\begin{array}{c}\text { Lower } \\
\text { Limit }\end{array}$ & Mean & $\begin{array}{c}\text { Upper } \\
\text { Limit }\end{array}$ & mf & $\begin{array}{c}\text { Lower } \\
\text { Limit }\end{array}$ & Mean & $\begin{array}{c}\text { Upper } \\
\text { Limit }\end{array}$ & mf & $\begin{array}{c}\text { Lower } \\
\text { Limit }\end{array}$ & $\begin{array}{c}\text { Mean } \\
\text { Upper } \\
\text { Limit }\end{array}$ \\
\hline 0 & 87 & 133.5 & 180 & 0 & -0.7 & 0.025 & 0.75 & 0 & 1.08 & 2.58 & 4.06 \\
\hline 1 & 115 & 150 & 185 & 1 & 0.04 & 0.77 & 1.5 & 1 & 1.25 & 1.7 & 2.14 \\
\hline
\end{tabular}

\section{Proposed Approach}

\subsection{General Structure of Proposed Approach}

The proposed system can classify chest CT scans as COVID19 and Normal with a fuzzy logic approach based on 3 distinctive statistical features (skewness, kurtosis, mean), highly relevant to the calculation of color distributions. These features allow distinguishing infected areas from the healthy which leads us to employ in this study. The chest CT scans of different patients were analyzed with these features. The proposed fuzzy logic method determines the output variable using membership functions assigned to input values and pre-defined rules. The general structure of the proposed system is shown in Figure 2.

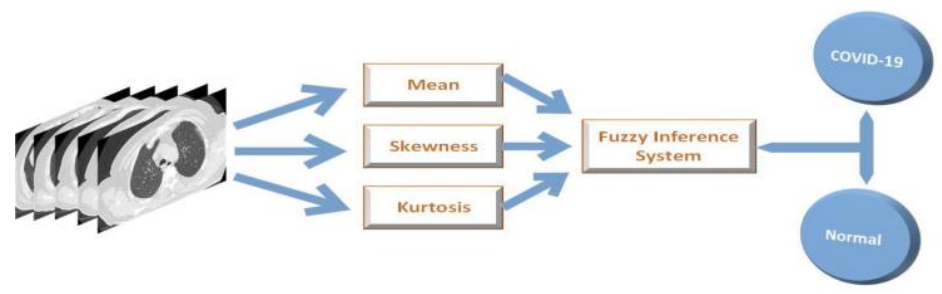

Figure 2. The general structure of the proposed system

Statistical analysis. The chest CT scans of a patient may belong to two classes; COVID-19 and Normal. The infected area with COVID-19 is defined as the ground glass opacity (GGO) which has a color distribution different than the healthy area. In the proposed model, statistical features including skewness, kurtosis, and mean were used to distinguish these two areas. Skewness characterizes the degree of asymmetry of the pixel distribution around the mean in a specified area and measures its deviation from the symmetrical distribution (Kuruvilla \& Gunavathi, 2014). Kurtosis is a statistical measure that measures the peakedness or flatness of distribution relative to a normal distribution (Kuruvilla \& Gunavathi, 2014). In other words, kurtosis identifies whether the tails of a given distribution contain extreme values. These features were calculated for 1200 chest CT slices of both COVID-19 and Normal chest CT scans. The calculations were analyzed and determined the upper, average, and lower limit values for three features of both classes.

Fuzzy logic. Here, MATLAB Fuzzy Logic Toolbox was used for the fuzzy logic classifier. The features after the statistical analysis are used as inputs in fuzzy logic. Every three inputs have two membership functions defined as mf. In fuzzy logic, there are different membership functions such as trimf, gaussian and trapezoidal. In our proposed fuzzy system, we used the trimf membership function which is found to be adequate for the extracted features based on extensive experimental studies. The pre-defined value ranges of statistical features and the membership functions are given in Table 1.

e-ISSN: 2148-2683
In the proposed classification model, we used the TakagiSugeno inference model because there are two constant output values. These constant values were determined as 1 for the COVID-19 class and 0 for the Normal class. After these input and output definitions, the fuzzy rule statements which control the output for our fuzzy system were determined. Consequently, the fuzzy classification system was created according to input variables, membership functions, and rule statements. The created fuzzy system can classify the chest CT scans of a patient based on statistical calculations and pre-defined fuzzy rules.

\subsection{Interface: COV-FUZZY}

The proposed fuzzy logic system is integrated with our custom-designed interface named COV-FUZZY developed in MATLAB App Designer, aiming to assist doctors in diagnosing the cases. In Figure 3 the screenshots of the COV-FUZZY interface demonstrate test results of different patients. The home page of the interface is given in Figure 3a. The folder of a patient can be selected to upload the chest CT slices, and then the slices can be viewed by moving the slider from top to down as shown in Figure 3b, Figure 3c, and Figure 3d. If the GGO patterns are detected in any slices, the red lamp lights up to alert. Otherwise, the green lamp lights up as shown in Figure $3 \mathrm{~d}$. If the chest CT scans cannot be matched with any classes, the 'Radiologist opinion is required lamp lights up and warns the doctor.

\section{Experimantal Evaluations}

\subsection{Dataset}

The dataset used in the study was provided by the Radiology Department of Izmir Bozyaka Training and Research Hospital. This dataset contains chest CT images of 30 COVID-19 infected and 30 Normal patients that are pre-diagnosed by expert radiologists. A chest CT scan of a patient consists of images that containing slices of the lung. Figure $4 \mathrm{a}$ shows examples of different slices of the chest CT scans with GGO finding from a patient diagnosed as COVID-19. There is no GGO findings in the slices which are shown in Figure $4 \mathrm{~b}$ taken from the chest CT scans of a normal patient.

\subsection{Result and Discussion}

The proposed fuzzy logic method is applied to the chest CT scans of a patient to make a binary classification as COVID-19 and normal. In the proposed system, the differences in color distributions between the two classes are distinguishable by the statistical features on the chest CT scans (skewness, kurtosis, and mean). 


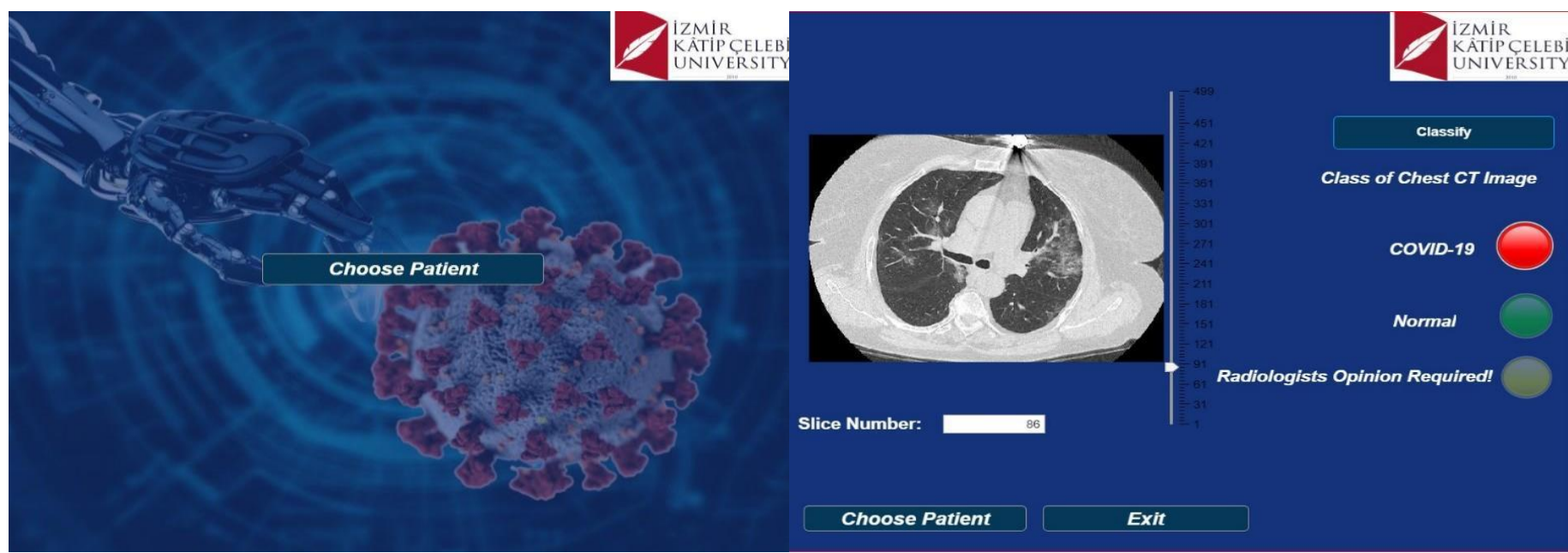

(a)

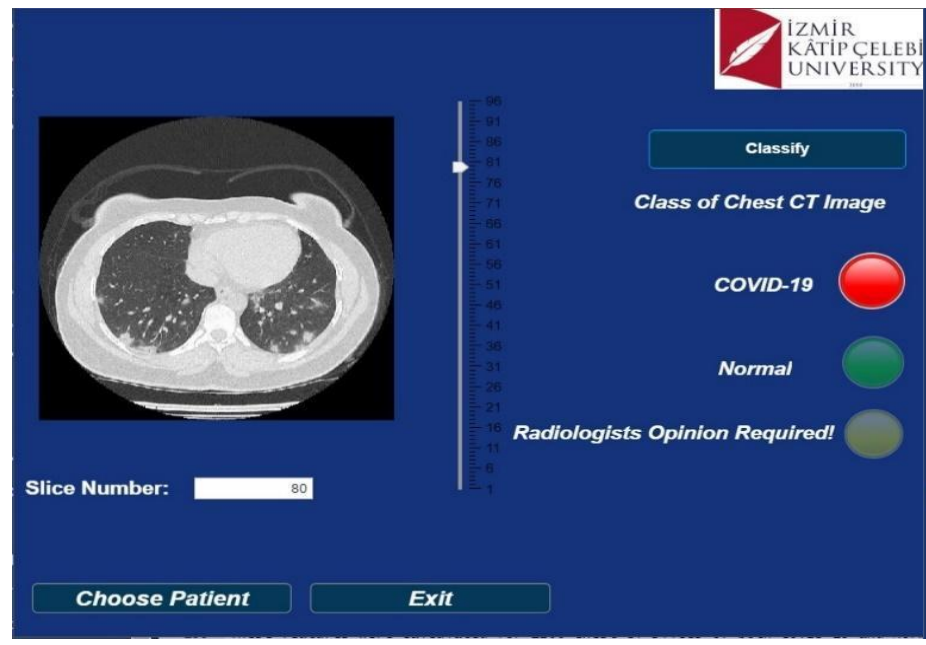

(c) (b)

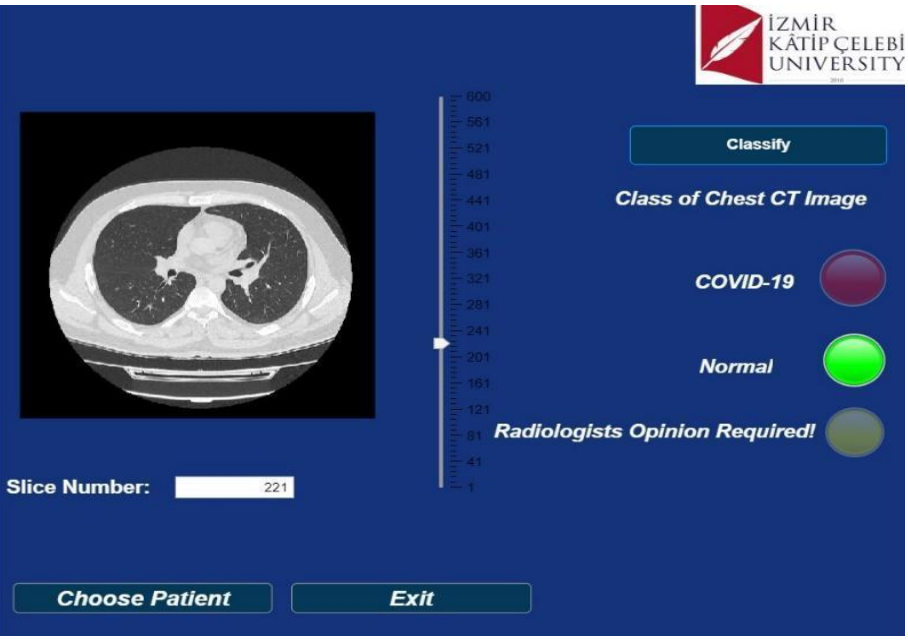

(d)

Figure 3. Our custom-designed COV-FUZZY interface
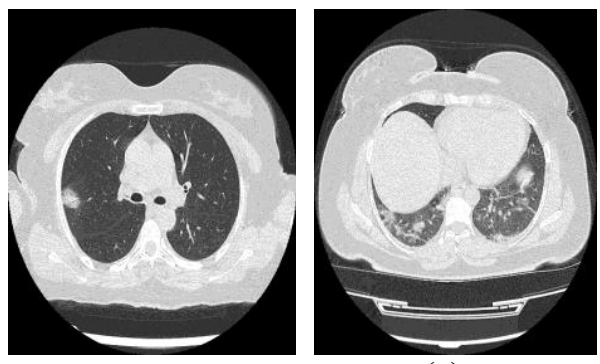

(a)
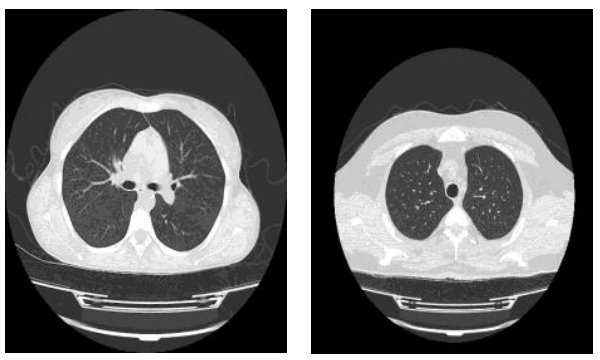

(b)

Figure 4. Examples images from (a) COVID-19 dataset (b) Normal dataset

The proposed fuzzy logic model uses these features as the inputs and employs fuzzy rules to generate the output. The COV-FUZZY interface is integrated with the proposed fuzzy logic classifier, and the proposed system is tested with the pre-diagnosed 60 patients including 30 COVID-19 patients and 30 Normal patients. It is demonstrated that the proposed system can assist radiologists in the diagnosis of COVID-19 by correctly classifying 40 out of 60 patients. The results show that the proposed model is capable of classifying COVID-19 cases, relying on fuzzy classifier and statistical features including skewness, kurtosis, and mean.

\section{Conclusions}

Early and accurate diagnosis is an important factor for the treatment of COVID-19 disease when considering the rapid spread of this epidemic. CT imaging is a reliable tool to be used in early diagnosis of COVID-19 cases. In this study, we proposed a fuzzy logic system to be employed on chest CT scans. In the proposed system, three statistical features, skewness, kurtosis, and mean, were used which allow distinguishing the GGO finding in the chest CT scans. The developed interface calculates the skewness, kurtosis, and mean values of the chest CT scans and then sends them to the proposed fuzzy logic classifier to determine its class. The results of the experiments show the advantage of our proposed method which leads to the potential interface for radiologists to improve their COVID-19 diagnosis. The proposed approach could be further improved by automatic segmentation of lesion region of CT scans which would be an interesting direction for future study. 


\section{References}

Ai, T., Yang, Z., Hou, H., Zhan, C., Chen, C., Lv, W., . . X Xia, L. (2020). Correlation of chest CT and RT-PCR testing for coronavirus disease 2019 (COVID-19) in China: a report of 1014 cases. Radiology, 296(2), E32-E40.

Anand, M. S., \& Tyagi, B. (2012). Design and implementation of fuzzy controller on FPGA. International Journal of Intelligent Systems and Applications, 4(10), 35-42.

Barro, S., \& Marín, R. (2001). Fuzzy logic in medicine (Vol. 83): Springer Science \& Business Media.

Barstugan, M., Ozkaya, U., \& Ozturk, S. (2020). Coronavirus (covid-19) classification using ct images by machine learning methods. arXiv preprint arXiv:2003.09424.

Carpenter, C. R., Mudd, P. A., West, C. P., Wilber, E., \& Wilber, S. T. (2020). Diagnosing COVID-19 in the emergency department: a scoping review of clinical examinations, laboratory tests, imaging accuracy, and biases. Academic Emergency Medicine, 27(8), 653-670.

Helmy, T., Al-Jamimi, H., Ahmed, B., \& Loqman, H. (2013). Fuzzy logic-based scheme for load balancing in grid services. Journal of Software Engineering and Applications, 5(12), 149.

Kamal, N. A., \& Ibrahim, A. M. (2018). Conventional, intelligent, and fractional-order control method for maximum power point tracking of a photovoltaic system: a review. Fractional Order Systems, 603-671.

Kamiya, A., Murayama, S., Kamiya, H., Yamashiro, T., Oshiro, Y., \& Tanaka, N. (2014). Kurtosis and skewness assessments of solid lung nodule density histograms: differentiating malignant from benign nodules on $\mathrm{CT}$. Japanese journal of radiology, 32(1), 14-21.

Kuruvilla, J., \& Gunavathi, K. (2014). Lung cancer classification using neural networks for CT images. Computer methods and programs in biomedicine, 113(1), 202-209.

Kuruvilla, J., \& Gunavathi, K. (2015). Lung cancer classification using fuzzy logic for CT images. International Journal of Medical Engineering and Informatics, 7(3), 233-249.

Mercan, Ö. B., \& K1lıç, V. (2020). Fuzzy classifier based colorimetric quantification using a smartphone. Paper presented at the International Conference on Intelligent and Fuzzy Systems.

ÖKÇÜN, S., KURNAZ, M., KOÇKAYA, G., Adile, A., SENER, O., \& TECIRLİ, G. COVID-19 TANI YÖNTEMLERINE BAKIŞ: HIZLI SISTEMATIKK INCELEME. Eurasian Journal of Health Technology Assessment, 4(2), 10-35.

Samuel, C. C., Saravanan, V., \& Devi, M. V. (2007). Lung nodule diagnosis from CT images using fuzzy logic. Paper presented at the International Conference on Computational Intelligence and Multimedia Applications (ICCIMA 2007).

Tiryaki, A. E., \& Kazan, R. (2007). Bulaşık makinesinin bulanık mantık ile modellenmesi. Mühendis ve Makine, 48(565), 3-8.

Wu, Y.-H., Gao, S.-H., Mei, J., Xu, J., Fan, D.-P., Zhang, R.-G., \& Cheng, M.-M. (2021). Jcs: An explainable covid-19 diagnosis system by joint classification and segmentation. IEEE Transactions on Image Processing, 30, 3113-3126. 